\title{
Change of the Salts Quantity and Type in the Irrigated Soils of the Mughan Plain and Their Impact on Plants Productivity
}

\author{
Mustafayev M. G. \\ National Academy of Sciences of the Azerbaijan Republic Institute of Soil Science and Aqrochemistry, Baku, Azerbaijan.
}

\begin{abstract}
How to cite this paper: Mustafayev M. G. (2020) Change of the Salts Quantity and Type in the Irrigated Soils of the Mughan Plain and Their Impact on Plants Productivity. International Journal of the Science of Food and Agriculture, 2020, 4(2), 101-108.

DOI: $10.26855 /$ ijfsa.2020.06.001
\end{abstract}

Received: February 25, 2020

Accepted: March16, 2020

Published: March 30, 2020

Corresponding author: Mustafayev M. G., National Academy of Sciences of the Azerbaijan Republic Institute of Soil Science and Aqrochemistry, Baku, Azerbaijan.

Email: meliorasiya58@mail.ru

\begin{abstract}
Change of the salts quantity and types in the Mughan plain and an impact of their amount on cotton and grain plant productivity have been determined. The researches show that the salts amount is different along profile in the irrigated soils of the Mughan plain, their increase towards depth was observed. The classical classifications were taken as a basis in definition of the salts type and it was determined that they were chlorine-sulfate and sulfate-chlorine in some places for the salts, type, change of the plants productivity depending on salts quantity and type shows that productivity of the cotton plant in the unsalted soils was $26,8 \mathrm{c} / \mathrm{h}$, these, indices were changed for both plants in the weak, middle and strong salinized soils as the following: $25,45 \mathrm{c} / \mathrm{h} ; 21,5 \mathrm{c} / \mathrm{h}, 12,65 \mathrm{c} / \mathrm{h}$; $7,52 \mathrm{c} / \mathrm{h}$.
\end{abstract}

\section{Keywords}

Salts, Types of Salts, Salinity Rates, Productivity, Groundwater, Groundwater Mineralization, Mineralization of Irrigation And Drainage Waters, Salt Reserves

\section{Introduction}

The Mughan plain is situated in the Kur-Araz lowland. It is one of the ancient regions which are busy with irrigation agriculture. A definite part of the soils exposed to the various salinization because the agrotechnical rules weren't followed correctly. Lately, the same defects were relatively removed as a result of restoration of the collector-drainage net and irrigation canals. The soil reform in the Republic aims to increase rationality of the agrarian industrial production and improvement of the population's food provision. From this point of view, study of the influence of the salts amount and type on plants productivity in the irrigated soils is an actual problem. During the research the areas where the cotton and grain plants were planted have been selected in the same zones. Change of the salts amount was studied. According to the consequences the salts type was determined under widely used classifications at present. Change of the salts resource, mineralization of ground, irrigation and drainage waters was determined to evaluate a contemporary state of soils. Alteration of the plants productivity depending on salts quantity was investigated at the end of the researches and the agromeliorative measures were offered with the purpose of the soils improvement and productivity increase in the same zones.

\section{Research Object and Methods}

The soils with the cotton and grain plants in the irrigated meadow-grey soils have been taken as a research 
object. It is in the Minbashi village of Sabirabad. Each of the experimental area occupies 2,5 hectares zone. With the purpose of investigation of the salts quantity in the soil, the soil and water samples were taken from the character places of the same zone and the chemical analyses were performed under the laboratorial condition. During the research the coordinates of the drilled soil cut places were fixed by GIS. All the chemical analyses were fulfilled by the most widely used methods at present [1].

\section{Analysis and Diseussions}

The Mughan plain is a part of the Kur-Araz lowland. It is separated from the Mil plain by the Araz river, but from the Shirvan plain by the Kur in the north-west it joins the Lankaran and Salyan plain in the south and south-east. The relief of the Mughan plain was created by an accumulative activity of the Kur and Araz rivers, its formation continued till last periods. There are alluvial-accumulative forms of the relief in here: sharp and high coast, ancient deep river-beds, bank roads and so on. Geology of the plain is belonged to the general historical geotectonics background of the Caspean Sea. As a consequence of the subsequent withdrawal of the Caspean Sea, the Kur depression became the eastern Transcaucasia and the-Kur-Araz lowland, while the sea withdrawing, they are covered with alluvial deposites, a climate of the Mughan plain was studied by I.V.Figurovsky and it was determined that it belonged to subtropical semidesert dry climate [2]. The average yearly temperature it $+14,1^{\circ} \mathrm{C}$. A relative humidity is $60 \%$ on average. The air dampness is high. An average yearly quantity of the atmospheric precipitations is $246-260 \mathrm{~mm}$, but an evaporation from the water surface reaches $950 \mathrm{~mm}$. An average monthly temperature of the soil surface is $1-3,5^{\circ} \mathrm{C}$ in January, $32-35^{\circ} \mathrm{C}$ in july. The plant cover of the Mughan plain concerns semidesert type, there are mainly 3 kinds: wormwood, saline, hollow plants. According to the climate condition the annual heat-loving plants, technical plant -cotton planting here is good. Diversity of the cultures was formed and they were subjected to variation in a large part of the zone. At present natural cultures can be met in the small areas of some places [3].

The soil cover of the Mughan plain was widely learnt by some researchers. The following soil types are available in the plain: grey-meadow less humic soils: greymeadow mean humic soils; grey-meadow high humic soils; primary-grey soils; meadow-grey soils. Later, main reasons of the Kur-Araz soils salinization were investigated by V. R.Volobuyev [4], G. Sh. Mammadov [5], M. P. Babaev and others [6]. The author separated the meadow-grey soils into saline-like, solonchak-like, merging, gleying, irrigating species and noted utilization of these soils under cotton, grain and orchard plants. But in amelioration area M. G. Mustafayev [7], G. Z. Azizov [8], M. G. Mustafaev [9], M. P. Babayev, G. G. Jabrailova, F. M. Mustafaev [10] and other specialists directed their researches to salinization and solonetzification of soils, investigation of the variasion happening in utilization period.

The subsoil waters level is near the earth surface, nutrition sources are the followings: irrigative waters, atmospheric precipitations, infiltration waters of the Kur and Araz rivers, the waters with the underground pressure. Nourishment of subsoil waters at the expense of the rainfalls happens in spring and autumn, and this index forms $8-10 \%$. The long researches show that there are pressure waters in Mughan and they are related with the subsoil waters. The same waters forms $15 \%-17 \%$ of the income part of the water balance. The subsoil waters level reaches 1,0-1,5 $\mathrm{m}$ during irrigations. They are hydrocarbonate by their chemical composition. In some places, we can found chlorine and sulphate types $[11,12]$. The salts amount, their type, the location depth of subsoil waters and alteration of their mineralization was widely studied by some researchers $[7,8,13]$ and others. The long researches show that incorrect irrigation of the soils under tillage, need and non-implementation of these measures in time cause the soils salinization and render their negative influence on agricultural plants which are grown there. On the other hand, one of the main reasons of the soils salinization is nearness of subsoil waters with high mineralization to the surface. While increasing the salts concentration in soil, development of both undersoil and land surface organs of plants weakens, productivity reduces. Generally, to achieve the salts decrease in soil, it is advisable to apply irrigative water according to the amount of plants. It was determined that correctly using of soils under tillage, applying of water for the plant's need, using of the fertilizers by norms in time caused decrease of the salts amount and increase of productivity (15\%-20\%) $[12,14]$.

As it is known that the soils in the Mughan plain are mainly used under the cotton plant. A need of the cotton plant for nutrient is higher than the other plants. That's why it is necessary to compensate a need of the plant for nutrient in time. For this purpose a state of the soils used under the cotton plant in the research area was studied, 
the soil cuts ( 5 sections) were applied in the character places of the same zone and the required chemical analyses were fulfilled.

Change of granulometric composition in soils was given on the following table (Table 1). As it is seen from Table 1 , a quantity of the particles less than $0,01 \mathrm{~mm}$ (physical clay) changes by $50,60 \%-68,58 \%$ along the profil. The soils are mean and heavy loamy by granulometric composition.

Table 1. Changes in granulometric composition of soils in practice

\begin{tabular}{|c|c|c|c|c|c|c|c|c|}
\hline \multirow{2}{*}{ Cuts No } & \multirow{2}{*}{ Depth,sm } & \multicolumn{7}{|c|}{ diameter of chmastits, $\mathrm{mm}$} \\
\hline & & $1-0.25$ & $0.25-0.05$ & $0.05-0.01$ & $0.01-0.005$ & $0.005-0.001$ & $<0.001$ & $<0.01$ \\
\hline \multirow[t]{3}{*}{1} & 2 & 3 & 4 & 5 & 6 & 7 & 8 & 9 \\
\hline & $0-22$ & 0,63 & 14,05 & 26,42 & 14,58 & 20,04 & 24,28 & 58,90 \\
\hline & $22-67$ & 0,95 & 19,37 & 23,76 & 15,24 & 19,12 & 21,56 & 55,92 \\
\hline \multirow[t]{5}{*}{ M-3 } & $67-105$ & 0,83 & 26,79 & 21,78 & 15,04 & 16,32 & 19,24 & 50,60 \\
\hline & $105-157$ & 0,65 & 22,39 & 24,32 & 16,28 & 17,84 & 18,52 & 52,64 \\
\hline & $157-200$ & 0,61 & 2,71 & 23,16 & 14,62 & 18,86 & 20,04 & 53,52 \\
\hline & $0-22$ & 0,35 & 15,51 & 19,90 & 19,90 & 21,40 & 22,94 & 64,24 \\
\hline & $22-67$ & 0,45 & 12,89 & 29,44 & 1,78 & 31,04 & 24,40 & 57,22 \\
\hline \multirow[t]{3}{*}{ M-5 } & $67-105$ & 0,25 & 18,17 & 27,04 & 12,08 & 23,34 & 19,12 & 54,54 \\
\hline & $105-157$ & 0,22 & 7,14 & 24,06 & 18,24 & 7,62 & 42,72 & 68,58 \\
\hline & $157-200$ & 0,38 & 14,52 & 19,70 & 8,66 & 26,64 & 30,10 & 65,40 \\
\hline
\end{tabular}

Development and productivity of the cotton plant on phases have been studied dependind on soils saltness during the research. During the vegetation period of the plant the phonological observations were performed, its growth, a quantity of its leaves and bolls have been defined. It was known that an exit and development of the plant was good in the places where an amount of salts is little.

The plant growth was $17-35 \mathrm{sm}$ in the places where the salts is more. A quantity of the opened bolls is 14 , an amount of unopened bolls-is 6-8 in the place with the saline spot. A growth of the plant is 157-158 sm, an amount of the opening bolls is 29 , but unopening bolls $-15-18$. We should note that the natural and weed grass is found in the area. Beside it the fissures depth has been measured and it was determined that their depth was $14-21 \mathrm{~cm}$ in the places with the weak saline spots.

The water of the concrete canal is used for irrigation of the area and its water is taken, the analyses were performed in the laboratory. So, a quantity of salts in the experimental soil, mineralization of subsoil and irrigative waters have been studied and the consequences have been given on the tables (Table 2, 3, 4). It was determined as a result of the analyses that $\mathrm{CO}_{3}$ ion wasn't observed in the water sample taken from the zone, but $\mathrm{HCO}_{3}$ ion vibrated by $0,012-0,107 \%$. A quantity of $\mathrm{Cl}$ ion was $0,016-0,250$.

The salts amount was $2,02-0,766 \%$ in these samples (for dry residue). $\mathrm{SO}_{4}$-quantity is $0,052-0,362 \%$ along the profile. The results show that the salts quantity begins to grow towards low layers of the soil (Table 2). As it is seen the soils of the experimental area are: un salinized, salinized to a weak and average degree.

Table 2. Changes in salt content in the meadow-gray soils in Mugan plain (2017)

\begin{tabular}{|c|c|c|c|c|c|c|c|c|c|c|}
\hline \multirow{2}{*}{ Cuts No } & \multirow{2}{*}{$\begin{array}{l}\text { Depth, } \\
\text { in sm }\end{array}$} & \multicolumn{2}{|c|}{$\mathrm{CO}_{3}$} & \multicolumn{2}{|c|}{$\mathrm{HCO}_{3}$} & \multicolumn{2}{|c|}{$\mathrm{SO}_{4}$} & \multicolumn{2}{|c|}{$\mathrm{CI}$} & \multirow{2}{*}{$\begin{array}{c}\text { Dry } \\
\text { residue, } \%\end{array}$} \\
\hline & & Mg-ekv & $\%$ & Mg-ekv & $\%$ & Mg-ekv & $\%$ & Mg-ekv & $\%$ & \\
\hline 1 & 2 & 3 & 4 & 5 & 6 & 7 & 8 & 9 & 10 & 11 \\
\hline \multirow{5}{*}{$\begin{array}{c}\text { M- } 1 \\
\text { N 39 } 53^{\prime} 36.78^{\prime \prime} \\
\text { E } 048^{\circ} 52^{\prime} 4.66^{\prime \prime} \\
\quad(h=-24)\end{array}$} & $0-21$ & no & no & 1,12 & 0,068 & 1,08 & 0,052 & 0,52 & 0,018 & 0,232 \\
\hline & $21-57$ & no & no & 1,00 & 0,061 & 2,16 & 0,103 & 0,92 & 0,033 & 0,308 \\
\hline & $57-91$ & no & no & 1,52 & 0,093 & 1,21 & 0,058 & 0,44 & 0,016 & 0,248 \\
\hline & $91-143$ & no & no & 1,48 & 0,090 & 1,42 & 0,068 & 0,52 & 0,018 & 0,292 \\
\hline & $143-200$ & no & no & 1,76 & 0,107 & 1,54 & 0,074 & 0,60 & 0,021 & 0,306 \\
\hline
\end{tabular}




\begin{tabular}{|c|c|c|c|c|c|c|c|c|c|c|}
\hline \multirow{5}{*}{$\begin{array}{c}\mathrm{M}-2 \\
\text { N 39 } 53^{\prime} 38.86^{\prime \prime} \\
\text { E } 048^{\circ} 52^{\prime} 4.21^{\prime \prime} \\
(\mathrm{h}=-24)\end{array}$} & $0-26$ & no & no & 0,52 & 0,032 & 2,24 & 0,108 & 0,56 & 0,020 & 0,290 \\
\hline & $26-51$ & no & no & 0,52 & 0,032 & 2,12 & 0,102 & 0,44 & 0,016 & 0,286 \\
\hline & $51-97$ & no & no & 0,40 & 0,024 & 3,44 & 0,165 & 0,44 & 0,016 & 0,424 \\
\hline & $97-159$ & no & no & 0,32 & 0,019 & 2,77 & 0,133 & 0,88 & 0,031 & 0,222 \\
\hline & $159-200$ & no & no & 0,28 & 0,017 & 3,63 & 0,174 & 0,68 & 0,024 & 0,258 \\
\hline \multirow{5}{*}{$\begin{array}{c}\text { M-3 } \\
\text { N 39 } 53^{\prime} 40.82^{\prime \prime} \\
\text { E } 048^{\circ} 52^{\prime} 4.17^{\prime \prime} \\
(\mathrm{h}=-24)\end{array}$} & $0-22$ & no & no & 0,28 & 0,017 & 6,47 & 0,310 & 1,36 & 0,048 & 0,540 \\
\hline & $22-67$ & no & no & 0,28 & 0,017 & 5,02 & 0,241 & 1,88 & 0,067 & 0,496 \\
\hline & $67-105$ & no & no & 0,20 & 0,012 & 7,53 & 0,362 & 2,03 & 0,074 & 0,570 \\
\hline & $105-157$ & no & no & 0,40 & 0,024 & 4,23 & 0,203 & 0,80 & 0,028 & 0,276 \\
\hline & $157-200$ & no & no & 0,48 & 0,029 & 2,11 & 0,101 & 0,80 & 0,028 & 0,206 \\
\hline \multirow{5}{*}{$\begin{array}{c}\text { M- } 4 \\
\text { N 39 } 53^{\prime} 42.84^{\prime \prime} \\
\text { E 048 } 52^{\prime} 4.20^{\prime \prime} \\
\quad(h=-23\end{array}$} & $0-19$ & no & no & 1,40 & 0,085 & 2,41 & 0,116 & 1,00 & 0,035 & 0,318 \\
\hline & $19-69$ & no & no & 1,04 & 0,063 & 3,46 & 0,166 & 1,44 & 0,051 & 0,306 \\
\hline & $69-117$ & no & no & 1,48 & 0,090 & 3,20 & 0,154 & 0,80 & 0,028 & 0,312 \\
\hline & $117-163$ & no & no & 1,12 & 0,068 & 2,45 & 0,117 & 0,84 & 0,030 & 0,318 \\
\hline & $163-200$ & no & no & 1,16 & 0,071 & 2,16 & 0,103 & 0,80 & 0,028 & 0,318 \\
\hline \multirow{5}{*}{$\begin{array}{c}M-5 \\
\text { N 39॰53'36.76" } \\
\text { E } 048^{\circ} 52^{\prime} 6.11^{\prime \prime} \\
(\mathrm{h}=-25)\end{array}$} & $0-19$ & no & no & 0,28 & 0,017 & 4,54 & 0,218 & 5,84 & 0,207 & 0,700 \\
\hline & $19-63$ & no & no & 0,32 & 0,019 & 4,21 & 0,202 & 7,04 & 0,250 & 0,766 \\
\hline & $63-97$ & no & no & 0,32 & 0,019 & 3,48 & 0,167 & 6,04 & 0,214 & 0,578 \\
\hline & $97-149$ & no & no & 0,32 & 0,019 & 3,70 & 0,177 & 6,44 & 0,229 & 0,654 \\
\hline & $149-200$ & no & no & 0,36 & 0,022 & 2,67 & 0,128 & 5,72 & 0,203 & 0,554 \\
\hline
\end{tabular}

Table 3. Changes in salt content in the meadow-gray soils in Mugan plain (2018)

\begin{tabular}{|c|c|c|c|c|c|c|c|c|c|c|}
\hline \multirow{2}{*}{ No. cuts } & \multirow{2}{*}{ Depth, in sm } & \multicolumn{2}{|c|}{$\mathrm{CO}_{3}$} & \multicolumn{2}{|c|}{$\mathrm{HCO}_{3}$} & \multicolumn{2}{|c|}{$\mathrm{SO}_{4}$} & \multicolumn{2}{|c|}{ CI } & \multirow{2}{*}{$\begin{array}{c}\text { Dry } \\
\text { residue,\% }\end{array}$} \\
\hline & & Mg-ekv & $\%$ & Mg-ekv & $\%$ & Mg-ekv & $\%$ & Mg-ekv & $\%$ & \\
\hline 1 & 2 & 3 & 4 & 5 & 6 & 7 & 8 & 9 & 10 & 11 \\
\hline $\begin{array}{c}\text { M-6 } \\
\text { N39 } 53^{\prime} 38.74^{\prime \prime} \\
\text { E 048 } 52^{\prime} 5.72^{\prime \prime} \\
(\mathrm{h}=-25)\end{array}$ & $\begin{array}{c}0-25 \\
25-50 \\
50-75 \\
75-100 \\
100-150 \\
150-200\end{array}$ & $\begin{array}{l}\text { no } \\
\text { no } \\
\text { no } \\
\text { no } \\
\text { no } \\
\text { no }\end{array}$ & $\begin{array}{l}\text { no } \\
\text { no } \\
\text { no } \\
\text { no } \\
\text { no } \\
\text { no }\end{array}$ & $\begin{array}{l}1,10 \\
1,20 \\
1,46 \\
1,67 \\
1,81 \\
1,79\end{array}$ & $\begin{array}{l}0,067 \\
0,073 \\
0,089 \\
0,102 \\
0,110 \\
0,109\end{array}$ & $\begin{array}{l}1,00 \\
2,10 \\
1,10 \\
1,30 \\
1,55 \\
1,65\end{array}$ & $\begin{array}{l}0,048 \\
0,101 \\
0,053 \\
0,062 \\
0,074 \\
0,079\end{array}$ & $\begin{array}{l}0,62 \\
0,86 \\
0,50 \\
0,55 \\
0,61 \\
0,58\end{array}$ & $\begin{array}{l}0,022 \\
0,030 \\
0,017 \\
0,019 \\
0,021 \\
0,020\end{array}$ & $\begin{array}{l}0,232 \\
0,316 \\
0,248 \\
0,296 \\
0,327 \\
0,298\end{array}$ \\
\hline $\begin{array}{c}\text { M-7 } \\
\text { N 3953'40.63" } \\
\text { E 048 } 52^{\prime} 5.65^{\prime \prime} \\
(\mathrm{h}=-24)\end{array}$ & $\begin{array}{c}0-25 \\
25-50 \\
50-75 \\
75-100 \\
100-150 \\
150-200\end{array}$ & $\begin{array}{l}\text { no } \\
\text { no } \\
\text { no } \\
\text { no } \\
\text { no } \\
\text { no }\end{array}$ & $\begin{array}{l}\text { no } \\
\text { no } \\
\text { no } \\
\text { no } \\
\text { no } \\
\text { no }\end{array}$ & $\begin{array}{l}0,55 \\
0,66 \\
0,58 \\
0,48 \\
0,36 \\
1,50\end{array}$ & $\begin{array}{l}0,033 \\
0,040 \\
0,035 \\
0,029 \\
0,022 \\
0,091\end{array}$ & $\begin{array}{l}2,10 \\
2,00 \\
3,65 \\
2,95 \\
3,75 \\
2,65\end{array}$ & $\begin{array}{l}0,101 \\
0,096 \\
0,175 \\
0,142 \\
0,179 \\
0,127\end{array}$ & $\begin{array}{l}0,58 \\
0,42 \\
0,46 \\
0,81 \\
0,76 \\
0,42\end{array}$ & $\begin{array}{l}0,020 \\
0,015 \\
0,016 \\
0,031 \\
0,028 \\
0,015\end{array}$ & $\begin{array}{l}0,228 \\
0,240 \\
0,285 \\
0,312 \\
0,434 \\
0,452\end{array}$ \\
\hline $\begin{array}{c}M-8 \\
\text { N 39॰53'42.62" } \\
\text { E 048 } 52^{\prime} 5.46^{\prime \prime} \\
(\mathrm{h}=-23)\end{array}$ & $\begin{array}{c}0-25 \\
25-50 \\
50-75 \\
75-100 \\
100-150 \\
150-200\end{array}$ & $\begin{array}{l}\text { no } \\
\text { no } \\
\text { no } \\
\text { no } \\
\text { no } \\
\text { no }\end{array}$ & $\begin{array}{l}\text { no } \\
\text { no } \\
\text { no } \\
\text { no } \\
\text { no } \\
\text { no }\end{array}$ & $\begin{array}{l}0,83 \\
1,29 \\
1,01 \\
0,82 \\
1,09 \\
1,15\end{array}$ & $\begin{array}{l}0,051 \\
0,079 \\
0,061 \\
0,050 \\
0,066 \\
0,070\end{array}$ & $\begin{array}{l}2,55 \\
2,42 \\
1,75 \\
2,10 \\
1,75 \\
1,96\end{array}$ & $\begin{array}{l}0,122 \\
0,116 \\
0,084 \\
0,101 \\
0,084 \\
0,094\end{array}$ & $\begin{array}{l}0,55 \\
0,58 \\
0,67 \\
0,55 \\
0,63 \\
0,69\end{array}$ & $\begin{array}{l}0,019 \\
0,020 \\
0,023 \\
0,019 \\
0,022 \\
0,024\end{array}$ & $\begin{array}{l}0,269 \\
0,357 \\
0,382 \\
0,278 \\
0,260 \\
0,283\end{array}$ \\
\hline
\end{tabular}

During the research mineralization of the subsoil waters was fixed and the consequences were given on Table 4.

Table 4. Change of groundwater mineralization in the practice area (2017-2019)

\begin{tabular}{|c|c|c|c|c|c|c|c|}
\hline \multirow{2}{*}{ No. cuts } & \multicolumn{2}{|c|}{$\mathrm{CO}_{3}$} & \multicolumn{2}{|c|}{$\mathrm{HCO}_{3}$} & \multicolumn{2}{|c|}{$\mathrm{Cl}$} & \multirow{2}{*}{$\begin{array}{c}\text { Dry } \\
\text { residue,g|1 }\end{array}$} \\
\hline & mg.ekv & $\mathrm{g} / 1$ & mg.ekv & $\mathrm{g} / 1$ & mg.ekv & $\mathrm{g} / 1$ & \\
\hline \multicolumn{8}{|c|}{2017} \\
\hline
\end{tabular}




\begin{tabular}{lllllllll}
\hline M-1 & no & no & 0,30 & 0,018 & 5,32 & 0,187 & 2,215 \\
M-3 & no & no & 0,45 & 0,027 & 5,80 & 0,203 & 2,435 \\
M-5 & no & no & 0,50 & 0,031 & 7,10 & 0,248 & 2,873 \\
& & & & 2018 & & & & \\
M-1 & no & no & 0,35 & 0,021 & 5,65 & 0,271 & 2,335 \\
M-3 & no & no & 0,50 & 0,030 & 5,97 & 0,287 & 2,571 \\
M-5 & no & no & 0,55 & 0,033 & 7,35 & 0,353 & 2,963 \\
M-1 & & & & & & & \\
M-3 & no & no & 0,40 & 0,024 & 5,82 & 0,279 & 2,387 \\
M-5 & no & no & 0,55 & 0,033 & 6,15 & 0,295 & 2,605 \\
\hline
\end{tabular}

The experiments show that mineralization of subsoil waters is various in these sections of the research zone$2,215-2,873 \mathrm{~g} / 1$ in 2017-2019; 2,335-2,963 $\mathrm{g} / 1$ and 2,387-2,981 $\mathrm{g} / 1, \mathrm{CO}_{3}$ ion wasn't observed in anions composition in the water samples taken from the same zone. $\mathrm{HCO}_{3}$ ion amount was $0,018-0,031 \mathrm{~g} / \mathrm{l} ; 0,021-0,033$ $\mathrm{g} / \mathrm{l}$ and $0,024-0,037 \mathrm{~g} / \mathrm{l}$ in the same years. $\mathrm{Cl}$ ion quantity was $0,187-0,248 \mathrm{~g} / \mathrm{l} ; 0,271-0,353 \mathrm{~g} / \mathrm{l}$ and $0,279-0,360 \mathrm{~g} / \mathrm{l}$. As it is seen the indicators of the subsoil waters mineralization and an amount of anions in their content increased slightly. One of the reasons is increase of mineralization of irrigation waters in the same zone and delay of the agromeliorative measures. One of the main parameters in meliorative state evaluation of soils is to study subsoil waters mineralization. The water samples have been taken from the irrigation canal used for irrigation of the same zone and chemical analyses have been fulfilled for the purpose of these problems solution. The results are given on the following table (Table 5).

Table 5. Changes in salt content in irrigation canals (2017-2019)

\begin{tabular}{|c|c|c|c|c|c|c|c|}
\hline \multirow{2}{*}{ Channel name } & \multicolumn{2}{|c|}{$\mathrm{CO}_{3}$} & \multicolumn{2}{|c|}{$\mathrm{HCO}_{3}$} & \multicolumn{2}{|c|}{$\mathrm{Cl}$} & \multirow{2}{*}{$\begin{array}{l}\text { Dry } \\
\text { residue,g|1 }\end{array}$} \\
\hline & mg.ekv & $\mathrm{g} / 1$ & mg.ekv & $\mathrm{g} / 1$ & mg.ekv & $\mathrm{g} / 1$ & \\
\hline \multicolumn{8}{|c|}{2017} \\
\hline $\begin{array}{l}\text { Concrete coating canal } \\
\qquad(10.06 .2017)\end{array}$ & no & no & 0,41 & 0,025 & 1,75 & 0,061 & 0,692 \\
\hline $\begin{array}{l}\text { Concrete coating canal } \\
\quad(10.09 .2017)\end{array}$ & no & no & 0,37 & 0,023 & 1,53 & 0,054 & 0,537 \\
\hline \multicolumn{8}{|c|}{2018} \\
\hline $\begin{array}{l}\text { Concrete coating canal } \\
\qquad(10.06 .2018)\end{array}$ & no & no & 0,44 & 0,027 & 1,61 & 0,056 & 0,675 \\
\hline $\begin{array}{l}\text { Concrete coating canal } \\
\qquad(10.06 .2018)\end{array}$ & no & no & 0,40 & 0,024 & 1,57 & 0,055 & 0,551 \\
\hline \multicolumn{8}{|c|}{2019} \\
\hline $\begin{array}{l}\text { Concrete coating canal } \\
\qquad(10.06 .2019)\end{array}$ & no & no & 0,43 & 0,026 & 1,64 & 0,057 & 0,681 \\
\hline $\begin{array}{l}\text { Concrete coating canal } \\
\qquad(10.06 .2019)\end{array}$ & no & no & 0,35 & 0,021 & 1,60 & 0,056 & 0,561 \\
\hline
\end{tabular}

$\mathrm{CO}_{3}$ wasn't observed in water sample taken from irrigation canal with the concrete coating which is situated at the edge of the experimental area. The consequences show that $\mathrm{HCO}_{3}$ quantity was $0,023-0,025 \mathrm{~g} / \mathrm{l}$, Cl$0,054-0,061 \mathrm{~g} / 1$. These indices are $0,024-0,027 \mathrm{~g} / 1$ and 0,055-0,56 g/l; 0,21-0,026 g/1 and 0,056-0,057 g/l in 2018-2019. Studying of the mineralization shows that their amount changed in comparison with 2017. So, their mineralization was $0,692-0,537 \mathrm{~g} / 1$ in 2017 , it changed by $0,675-0,551 \mathrm{~g} / 1$ and $0,681-0,551 \mathrm{~g} / 1$ in $2018-2019$. 
According to the researches, if we take into account that mineralization of irrigation mineralization is less than 1,0 $\mathrm{g} / \mathrm{l}$, we can show that they are good for irrigation. The available classifications were used for definition of the salts type in the research soils. The same classifications were widely applied and they are used in the republic and in the UIS countries (union of independent States) at present. The same classifications are given below:

Table 6. Types of salinity depending on the amount of chlorine

\begin{tabular}{cc}
\hline Types of salinization & Ratio of total chlorine and salts soluble \\
\hline Chlorine & $>0,4$ \\
Sulfate-chlorine & $0,25-0,40$ \\
Chlorinated sulfate & $0,12-0,25$ \\
Sulfate & $<0,12$ \\
\hline
\end{tabular}

Table 7. Permissible limit of ions in different salinity types (NI Basilevich, YI Pankova, 1985)

\begin{tabular}{cccccc}
\hline $\mathrm{CO}_{3}$ & $\mathrm{HCO}_{3}$ & $\mathrm{CI}$ & Sulfate or chlorinated carbon & Chlorine-soda, soda-chlorine, sulphate-chlorine & $\begin{array}{c}\text { Sulfate- } \\
\text { sodium }\end{array}$ \\
\hline$<\frac{0,001}{0,03}$ & $\frac{0,08}{1,4}$ & $\frac{0,01}{0,3}$ & $\frac{0,04}{0,9}$ & $\frac{0,01}{0,3}$ & $\frac{0,02}{0,5}$ \\
\hline
\end{tabular}

Table 8. Classical salinity types

\begin{tabular}{ccc}
\hline Types of salinization & $\mathrm{CI} / \mathrm{SO}_{4}$ & $\mathrm{HCO}_{3} / \mathrm{CI}+\mathrm{SO}_{4}$ \\
\hline Chlorine & $>2,0$ & - \\
Sulfate-chlorine & $2-1$ & - \\
Chlorinated sulfate & $1-0,2$ & 1 \\
Sulfate & $<0,2$ & 1 \\
Carbonate-sulphate & $<0,2$ & 2 \\
Sulfate-soda & - & 1 \\
\hline
\end{tabular}

It was determined that $\mathrm{Cl}$-ion amount in the experimental area was $10-23 \%$ and $25-34 \%$ and $\mathrm{Cl} / \mathrm{SO}_{4}(1-0,2$ and $2-1)$, therefore, the salts type is chlorine-sulphatic and sulphate-chlorine in some places. One of the main factors in an evaluation of the ecomeliorative state in soils is to study irrigation regime, water -salts elements. With the purpose of these problems solution the following indicators are fixed:

-an average index was fixed and a quantity of irrigation waters were taken into account to fix the salts quantity entering the experimental area with irrigation waters:

Knowing of irrigation water amount $\left(3000-3350 \mathrm{~m}^{3} / \mathrm{h}\right.$ ) we can calculate the salt quantity by the following formula [15]:

$$
S_{\text {water }}=V \cdot S m
$$

Here, $S_{\text {water }}-$ a quantity of salt entering the soil with irrigation waters;

$\mathrm{V}$-irrigation waters amount, $\mathrm{m}^{3} / \mathrm{h}$;

$\mathrm{S}_{\mathrm{m}}$-irrigation waters mineralization, $\mathrm{g} / \mathrm{l}$.

According to the abovementioned formula we can fix a salt quantity entering the experimental area with irrigation waters for 2017-2019.

2017: $S_{\text {water }}=V \cdot S m=3000 \mathrm{~m}^{3} / \mathrm{h} \cdot 0,614 \mathrm{~g} / \mathrm{l}=1,84 \mathrm{t} / \mathrm{h}$

2018: $S_{\text {water }}=V \cdot S m=3250 \mathrm{~m}^{3} / \mathrm{h} \cdot 0,613 \mathrm{~g} / \mathrm{l}=1,99 \mathrm{t} / \mathrm{h}$

2019: $S_{\text {water }}=V \cdot S m=3350 \mathrm{~m}^{3} / \mathrm{h} \cdot 0,621 \mathrm{~g} / \mathrm{l}=2,08 \mathrm{t} / \mathrm{h}$

The consequences show that $1,84 \mathrm{t} / \mathrm{h} ; 1,99 \mathrm{t} / \mathrm{h}$ and $2,08 \mathrm{t} / \mathrm{h}$ salt entered the experimental area with the irrigative waters in 2017-2019.

The drains which act in the experimental area are covered drains and work satisfactorily. While fixing the salts quantity removed from experimental area by drainage waters during the research, the average values of the drainage flow and minerality have been used. The results of the analyses show that the values of the drainage were 
flow in the experimental area $163,0-1700,5-1710,3 \mathrm{~m}^{3} / \mathrm{h}$ in $2017-2019$, their minerality was 4,27-4,73-5,12 $\mathrm{g} / 1$. Taking into account the indices an amount of salts removed from the experimental area by drainage was fixed with the following formula: $S_{d}=D \cdot S_{d m}$

Here $S_{d}$-an amout of salts removed by drainage; $\mathrm{t} / \mathrm{h}$

$D$ - a quantity of drainage flow, $\mathrm{m}^{3} / \mathrm{h} ; S_{d m}$-minerality of drainage waters, $\mathrm{g} / \mathrm{l}$.

A quantity of salts removed from experimental area by drainage in 2017 :

$S_{d}=D \cdot S_{d m}=1630,0 \mathrm{~m}^{3} / \mathrm{h} \bullet 4,27 \mathrm{~g} / \mathrm{l}=6,96 \mathrm{t} / \mathrm{h}$;

2018: $S_{d}=D \cdot S_{d m}=1700,5 \mathrm{~m}^{3} / \mathrm{h} \cdot 4,73 \mathrm{~g} / \mathrm{l}=8,04 \mathrm{t} / \mathrm{h}$;

2019: $S_{d}=D \cdot S_{d m}=1710,3 \mathrm{~m}^{3} / \mathrm{h} \cdot 5,12 \mathrm{~g} / \mathrm{l}=8,77 \mathrm{t} / \mathrm{h}$;

The calculations show that an amount of salts removed by the drainage was $6,96 \mathrm{t} / \mathrm{h}$ in $2017 ; 8,04 \mathrm{t} / \mathrm{ha}$ in 2018 ; $8,77 \mathrm{t} / \mathrm{h}$ in 2019 . The results of the researches show that an amount of salts removed by the drainage is more in comparison with the quantity of salts entered with irrigation water. Studying of the salts supply in keeping the salts amount in the irrigation soils at optimum level and in preparation of the complex meliorative measures against salinization is one of the important problems. The average values of the salts quantity in the soil cuts applied in character places have been taken into consideration, the values of the salts supply have been fixed by the following formula: (at 0-100 and 100-200 cm)

\section{$\mathrm{S}=\mathrm{C}_{\mathrm{o}} \mathrm{hd}$}

Here S-salts supply, t/h, $\mathrm{C}_{0}$-salts quantity, \%, d-bulky weight, $\mathrm{g} / \mathrm{cm}^{3}, \mathrm{~h}$-density of account layer, $\mathrm{cm}$. The average values of the bulky weight on the shown lasyers were 1,$28 ; 1,31$ and $1,34 \mathrm{~g} / \mathrm{cm}^{3}$ at $0-100 \mathrm{~cm}$ and $100-200$ cm layers in 2017-2018-2019.

An average value of the salts at $0-100 \mathrm{~cm}, 100-200 \mathrm{~cm}$ layers was $0,255-0,335-0,558 \%$ in 2017; $0,266-0,378-0,575 \%$ in $2018 ; 0,247-0,364-0,544 \%$ in 2019 . The consequences were given on Table $3,3,7$. A comparison of the results shows that very weak salinization process occurs in the experimental area.

Table 9. Salt Reserves and salt reserves in practice soils (2017-2019)

\begin{tabular}{|c|c|c|c|}
\hline \multirow{2}{*}{ Depth, sm } & \multicolumn{3}{|c|}{ Salt content, $\%$} \\
\hline & 2017 & 2018 & 2019 \\
\hline 1 & 2 & 3 & 4 \\
\hline $0-100$ & 0.255 & 0.266 & 0.247 \\
\hline $100-200$ & 0.335 & 0.378 & 0.364 \\
\hline $0-200$ & 0.558 & 0.575 & 0.544 \\
\hline \multicolumn{4}{|c|}{ Salt reserve, $\mathrm{t} / \mathrm{ha}$} \\
\hline $0-100$ & 32,64 & 34,05 & 31,62 \\
\hline $100-200$ & 43,88 & 49,52 & 47,68 \\
\hline $0-200$ & 149,54 & 154,10 & 145.79 \\
\hline
\end{tabular}

An amount of the salts supply at 0-200 cm layer was calculated and their quantity was $149,54 \mathrm{t} / \mathrm{h}$ in 2017 ; $154,10 \mathrm{t} / \mathrm{h}$ and 145,79 $\mathrm{t} / \mathrm{h}$ in 2018 and 2019. As it is seen the salts amount reduced at the end of the research and this shows that desaltation process goes weakly towards depth.

The researches show that one of the main reasons for decrease of the agricultural plants productivity is the salts salinization process. While increasing the salts amount the plants development weakens and their productivity reduces. Change of the salts quantity and type was studied and their impact on the cotton productivity was determined during the research. For this purpose the small pitches have been selected (character places by taking into account the salts quantity). The change of the cotton plant productivity was investigated. The consequences show that the cotton productivity strongly reduces depending on saltness. The results have been shown on the following table (Table 10).

Table 10. Dependence on the amount of salts in the soil and the productivity of the cotton plant

\begin{tabular}{ccccccc}
\hline \multirow{2}{*}{ № } & $\begin{array}{c}\text { Productivity } \\
\text { indicators }\end{array}$ & $<0,25$ & $0,25-0,50$ & $0,5-1,0$ & $1,0-1,5$ & $1,5-2,0$ \\
\hline 1 & Average productivity, s/ha & 26,8 & 25,45 & 21,15 & 12,65 & 7,52 \\
\hline
\end{tabular}




\begin{tabular}{rrrrrrr}
\hline 2 & Product loss, s/ha & --- & 1,35 & 5,65 & 14,15 & 19,28 \\
3 & Product loss, in \% & --- & 5,04 & 21,08 & 52,79 & 71,94 \\
\hline
\end{tabular}

As it is seen from the table, the cotton productivity strongly reduces while the salts quantity gets increased. Though the productivity is $26,8 \mathrm{c} / \mathrm{h}$ in the areas where the soils aren't salinized, the productivity in the weak salted areas is $25,45 \mathrm{c} / \mathrm{h}$ or $1,35 \mathrm{c} / \mathrm{h}(5,04 \%)$. The productivity in the places salinized to a moderate degree was 21,15 or $5,65(21,08 \%) \mathrm{c} / \mathrm{h}$. These indicators in the places salinized to a strong and the strongest degree changed as the following: $12,65 \mathrm{c} / \mathrm{h}$ or $14,15 \mathrm{c} / \mathrm{h}(52,79 \%) ; 7,52 \mathrm{c} / \mathrm{h}$ or $19,28 \mathrm{c} / \mathrm{h}(71,94 \%)$. Reduction of the productivity was $52,79-71,94 \%$ in the places where the salts quantity was more than $1,0 \%$. Therefore, salt-endurance of plants was studied and their planting must be correctly organized. The agromeliorative and agrotechnical measures must be complexly applied, new progressive technologies, the local fertilizers must be used, minimum cultivating methods must be preferred for the purpose of getting high productivity. If these measures are correctly applied, they will be a reason for improvement of the fertility indicators of soils and satisfaction of their ecomeliorative state for a long time.

\section{References}

[1] Arinushkina, E. V. Guides on chemical analysis of lands. M.Issue. MSU, 1970, p. 488.

[2] Figurovsk,y I. V. Climate zoning of Azerbaijan.Material for climate zoning of Azerbaijan SSR,no.4,Baku(1936) pp. 3-17.

[3] Azizov, Q. Z. and Mustafayev, M. G. Salinity of soil and mineralization of subsoil waters in the part of the pipe ine of Baki-Tbilisi-Ceyhan passing from the zone of the republic of Azerbaijan//Ekoenergetika » journal, № 2 Baku, 2010, pp. 10-16.

[4] Volobuev V. R. Genetical forms of soil salinity Kur-Araz lowland. Baku (1965) 246 p.

[5] Mammadov, G. Sh. Motivations of Soil Science and soil geography,Baku,“Elm”, 2007, p. 664.

[6] Babayev, M. P. and Gurbanov, E. A. Mapping of the soils degradation in the Kur-Araz lowland. Works collection of ATS, XI vol. I part, "Elm” pub. 2010, pp. 55-61.

[7] Mustafayev, M. G. Change of mineralizetion of collector-drenage and irrigative waters in the soils of the farmer Economy "Shafag" which is situated in the massif of the Mugan-Salyan .Bulletin of the Belarussian state agrocultural academy,Qorki, №4, 2009, pp. 156-159.

[8] Azizov, K. Z. Water-salt balance of the reclamated soils of the Kur-Araz valley and analysis of its results. Baku "Science", 2006, 258 p.

[9] Mustafayev, M. G. Reason for the decrease in the efficiency of agricultural production on the lands of Azerbaijan.//Agrochemical news, №3, "SAM-Polygrafist”, Moscow, 2012, pp. 43-45.

[10] Babaev, M. P., Jabrailova, G. G. and Mustafaev, F. M. Study of desalination of irrigated soils in the Mugan steppe under the influence of vegetation irrigation. Russ.Academy of Agricul named after P.A.Kostichev, Coll. Sci.works, issne 9, c. Riazan, 2011, pp. 110-117.

[11] Mustafayev, M. G. Some problems of saline soil reclamation of Azerbaijan//Scientific research in land reclamation and water management, Sb. nauch. trudov,T-49, issue 1, LLP, KazNIIVH, 2012, pp. 106-110.

[12] Mustafayev, M. G. Water and physical characteristics of irrigated soils in the Massif of Mugan-Salyan.Polish Academy of Sciences,Committee for Land Reclamation journal of water and land evelopment and Environmental Engineering in Agriculture,Water Land Dev. Polsha, 2012, No.17(VII-XII):61-67 PL ISSN 1429-7426.

[13] Mustafayev, M. G. Criteriya for the evaluation of reclamation status of soils in the Mugan-Salyan massif./Polish Academy of Sciences, Committee for Land Reclamation and Environmental Engineering in Agriculture, Institut of Technologiy and Life Sciences. //Journal of water and land development, № 24, (I -III ), Poland, 2015, pp. 21-26.

[14] Mustafayev, M. G., Mazhaysky Yu.A., and Vinoqradov, D. V. Diagnostic Parameters of Irrigated Meadow-Serozemic and Alluvial Meadow Soils of the Mugan-Sal'yany Massif of Azerbaijan.// Russian Agricultural Sciences, Moskva, 2018,Vol. 44, No. 6, pp. 551-558.

[15] Averyanov, S. F. Some of the salinization prevention of irrigated soils and measures for to combat with it in the European part of the USSR. In the book. Irrigated agriculture in the European part of the USSR. Ed. "KOLOS", Moscow, (1965) pp. $25-63$. 